\title{
PERSPEKTIF ETIKA ISLAM TERHADAP HEDONISME PEMELUK AGAMA
}

\author{
Oleh: M. Bashori Muchsin \\ Pengajar pada Fakultas Ilmu Administrasi \\ Universitas Islam Malang \\ Email : cakbasuim@yahoo.com
}

\begin{abstract}
Abstrak
Di tengah masyarakat Indonesia ini, fakta menunjukkan bahwa tidak sedikit ditemukan kasus pemeluk agama yang menjerumuskan dirinya dalam perbuatan tercela, padahal agama Islam sudah mengajarkan kepada setiap pemeluknya untuk menjadi manusia-manusia yang taat dan konsisten memegang teguh agamanya. Mereka yang terjerumus ini identic membenarkan jenis-jenis perilaku yang bertentangan dengan doktrin Islam, dan bahkan apa yang diperbuatnya ini bukan hanya merugikan dirinya, melainkan juga merugikan orang lain dan citra agama yang dipeluknya. Salah satu pola yang diikutinya adalah hedonism.
\end{abstract}

Kata kunci: perubahan, pemeluk agama, hedonisme, etika Islam

\section{Abstract}

In the midst of Indonesian society, the facts show that there are not a few cases of adherents of religion who plunged themselves into despicable acts, even though Islam has taught each of its adherents to be obedient and consistent humans upholding their religion. Those who fall into identically justify the types of behavior that are contrary to Islamic doctrine, and even what it does is not only damage to itself, but also harms others and the religious image that is embraced. One pattern that he followed was hedonism.

Keywords: change, adherents of religion, hedonism, Islamic ethics

\section{PENDAHULUAN}

Di masyarakat ini, banyak dan beragam terjadi perilaku deviasi atau berkategori menyimpang secara moral dan agama. Diyakini, bahwa meeka yang terseret atau terjerumus menjadi pelakunya ini paham atau mengerti kalau yang dilakukannya sebagia bentuk pelanggaran.

Dalam kasus pelanggaran moral dan agama itu, terkadang ada yang tergolong sebagai tokoh agama atau seseorang yang mendapatkan kepercayaan dari masyarakat untuk menjalankan tugas-tugas yang berkaitan dengan aktifitas keagamaan atau ritualitas spiritualitas. 
Sebagai sampel, beberapa tahun lalu, ada pemberitaan dari berbagai media cetak maupun elektronik tentang kasus asusila yang layak disebut memprhatinkan. Diberitakan, bahwa Kabupaten Bogor digemparkan oleh kasus video asusila yang menyeret salah seorang pengurus Majelis Ulama Indonesia (MUI) di wilayah itu. Berita ini beredar selama sepekan di wilayah Kabupaten Bogor.

Kasus video asusila (saat itu sebenarnya kalangan tokoh agama berharap tidak benar) yang berdurasi sekitar 6 menit yang menayangkan adegan tidak pantas antara tokoh agama itu dengan dua orang wanita.

Kasus pelanggaran moral seperti itu memang sudah sering terjadi atau dari waktu ke waktu ada saja, akan tetapi yang melibatkan tokoh agama, barangkali termasuk langka, sehingga tidak selayaknya dijadikan pembenar kalau moralitas tokoh agama di negeri ini sedang di simpang jalan atau dalam gugatan public secara serius.

Meski begitu, para pemeluk agama di negara bergelar the biggest Moslem community in the world ini tetap wajib digugat, pasalnya ada kecenderungan kuat yang terjadi di tengah masyarakat, kalau pola hedonisme dengan menempatkan hubungan seks bebas dan industri pornografi semakin mendapatkan tempat.

Sebagai sampel pelajaran lagi, pernah Direktorat Tindak Pidana Ekonomi Khusus Bareskrim Polri menemukan total 120.000 video porno yang di dalamnya melibatkan anak-anak. Temuan ini membenarkan kasus video asusila tokoh agama, bahwa pola hedonisme masyarakat atau sekelompok orang semakin memprihatinkan. Mulai dari anak hingga tokoh agama dijadikannya sebagai bagian dari industri pornografi.

Kasus industri pornografi itu tidak akan pernah terjadi, manakala kondisi masyarakat tidak terjerumus dalam hedonisme gaya hidup. Seorang tokoh agama tidak akan sampai memasuki ranah komiditi vedo asusila, kalau dirinya tidak terseret dalam pencarian dan petualangan seks bebas. Sementara itu, petualangan pemenuhan kebutuhan biologis ini identik dengan pemenangan hedonisme.

\section{PEMBAHASAN}

\section{Memahami Esensi dan Fungsi Agama}

Banyak pertanyaan yang bersifat sebagai gugatan terhadap masyarakat Indonesia, seperti masihkah wahyu ilahi menjadi pondasi negeri ini? Jawabannya "masih". Cuma banyak orang pintar yang beragama dan berkedudukan yang tidak menjadikan wahyu (agama) sebagai pijakan utamanya. Mereka terbuai oleh ambisi dan kesenangan serta kepuasan duniawi yang menggiringnya menjatuhkan pilihan untuk meminggirkan atau 
mendegradasikan wahyu (Tuhan) atau menjadikan agama tidak berguna dalam hidupnya di dunia dan akhirat.

Kalangan pembelajar tentu sudah banyak paham atau mengerti istilah agama. Dapat dibaca dari satu pengertian, bahwa istilah Agama dalam bahasa sansekerta terdiri dari kosa kata "a" berarti "tidak" dan "gama" yang berarti kacau. Jadi kalau kedua kata itu digabungkan maka agama berarti tidak kacau. Istilah yang ke dua adalah "ugama" yang berarti "peraturan", "tata tertib", "hukum taurat". Dari kedua kata diatas dapat disimpulkan bahwa agama adalah upaya manusia untuk mengaitkan dan menyesuaikan seluruh hidupnya dengan tata tertib, hukum serta peraturan Ilahi, sehingga relasi atau hubungan dengan yang Ilahi (hablumminallah), manusia dan alam dapat berjalan dengan baik dan tertib. Dalam bahasa latin agama' disebut "religeo" kata ini berasal dari akar kata "religere" yang berarti "mengembalikan ikatan", "mengikatkan kembali". Dari istilah ini apat diartikan bahwa "agama" usaha manusia untuk mengembalikan, memulihkan hubungan yang rusak antara manusia dengan Allah. Hubungan yang rusak antara manusia dengan Allah pertama sekali terjadi ketika manusia (Adam dan Hawa) jatuh dalam dosa. ${ }^{1}$

Menurut Emile Durkhien, bahwa agama merupakan kekuatan yang sangat mempengaruhi sikap hidup manusia secara individual maupun sosial. Sementara menurut Franz Dahler mengatakan, bahwa agama adalah hubungan manusia dengan kekuasaan yang suci, dimana kekuasaan yang suci tersebut lebih tinggi dari adanya manusia. Hal yang sama dengan ini Banawiratman mengatakan bahwa agama bukan hanya ajaran teoritis, merumuskan iman dan mengarahkan prilaku orang beriman, melainkan juga didalamnya terdapat norma dan aturan, perintah, dan larangan yang berkenaan dengan etika dan moral masyarakat. Dari beberapa pemahaman di atas dapat kita menarik benang merah, bahwa nilai-nilai agama sudah ada dalam diri manusia dan nilai-nilai tersebut sangat mempengaruhi nilai hidup manusia sehingga ia memiliki kesadaran bahwa di luar dirinya ada sesuatu yang lebih tinggi, lebih suci dari dirinya. ${ }^{2}$

Ada beberapa alasan tentang mengapa agama itu sangat penting dalam kehidupan manusia, antara lain adalah :

1) Karena agama merupakan sumber moral

2) Karena agama merupakan petunjuk kebenaran

3) Karena agama merupakan sumber informasi tentang masalah metafisika. 
4) Karena agama memberikan bimbingan rohani bagi manusia baik di kala suka, maupun di kala duka.

Manusia sejak dilahirkan ke dunia ini dalam keadaan lemah dan tidak berdaya, serta tidak mengetahui apa-apa sebagaimana firman Allah dalam Q. S. al-Nahl (16): 78), yang berbunyi “Allah mengeluarkan kamu dari perut ibumu dalam keadaan tidak tahu apa-apa. Dia menjadikan untukmu pendengaran, penglihatan dan hati, tetapi sedikit di antara mereka yang mensyukurinya".

Dalam keadaan demikian itu, manusia senantiasa dipengaruhi oleh berbagai macam godaan dan rayuan, baik dari dalam, maupun dari luar dirinya. Godaan dan rayuan daridalam diri manusia dibagi menjadi dua bagian, yaitu

1) Godaan dan rayuan yang berysaha menarik manusia ke dalam lingkungan kebaikan, yang menurut istilah Al-Gazali dalam bukunya ihya ulumuddin disebut dengan malak Al-hidayah yaitu kekuatankekuatan yang berusaha menarik manusia kepada hidayah ataukebaikan.

2) Godaan dan rayuan yang berusaha memperdayakan manusia kepada kejahatan,yang menurut istilah Al-Gazali dinamakan malak alghiwayah, yakni kekuatan-kekuatan yang berusaha menarik manusia kepada kejahatan

Disinilah letak fungsi agama dalam kehidupan manusia, yaitu membimbing manusia kejalan yang baik dan menghindarkan manusia dari kejahatan atau kemungkaran. ${ }^{3}$

Dari segi pragmatisme, seseorang itu menganut sesuatu agama adalah disebabkan oleh fungsinya. Bagi kebanyakan orang, agama itu berfungsi untuk menjaga kebahagiaan hidup. Tetapi dari segi sains sosial, fungsi agama mempunyai dimensi yang lain seperti apa yang dihuraikan di bawah:

1) Memberi pandangan dunia kepada satu-satu budaya manusia. Agama dikatankan memberi pandangan dunia kepada manusia kerana ia sentiasanya memberi penerangan mengenai dunia(sebagai satu keseluruhan), dan juga kedudukan manusia di dalam dunia. Penerangan bagi pekara ini sebenarnya sukar dicapai melalui inderia manusia, melainkan sedikit penerangan daripada falsafah. Contohnya, agama Islam menerangkan kepada umatnya bahawa dunia adalah ciptaan Allah SWTdan setiap manusia harus menaati Allah SWT.

\footnotetext{
${ }^{3}$ Abdain,http://abdain.wordpress.com/2010/04/11/fungsi-agama-bagi-kehidupan/.
} Akses 15 Maret 2019. 
2) Menjawab pelbagai soalan yang tidak mampu dijawab oleh manusia. Sesetangah soalan yang sentiasa ditanya oleh manusia merupakan soalan yang tidak terjawab oleh akal manusia sendiri. Contohnya soalan kehidupan selepas mati, matlamat menarik dan untuk menjawabnya adalah perlu. Maka, agama itulah berfungsi untuk menjawab soalansoalan ini.

3) Memberi rasa kekitaan kepada sesuatu kelompok manusia. Agama merupakan satu faktor dalam pembentukkan kelompok manusia. Ini adalah kerana sistem agama menimbulkan keseragaman bukan sahaja kepercayaan yang sama, malah tingkah laku, pandangan dunia dan nilai yang sama. ${ }^{4}$

\section{Menghadapi Ilah Kontemporer}

Idealitasnya, dari doktrin etik keagamaan, sejatinya manusia tetap punya kiblat norma kebenaran, kejujuran, dan keselamatan, pasalnya di dalam wahyu Tuhan, ada bermacam-macam panduan yang bisa dijadikan manusia untuk membangun atau mendisain wajah budaya, politik, pendidikan, hukum, ideologi, dan ekonomi.

Doktrin keagamaan tersebut dipercayakan pada para agamawan untuk membumikannya. Mereka ditunjuk oleh Tuhan sebagai "manusia pilihan" atau "rasul" yang bukan sekedar melakukan perubahan, tetapi juga menyemaikan dan menyuburkan pencerahan moral dimana-mana.

Ironisnya lagi, mereka terkadang masih lebih menyukai dan membanggakan hidup tanpa wakyu. Nilai-nilai etik seperti kejujuran, keadilan, kemanusiaan, dan pemartabatan diri (seperti menjauhi perzinahan), bukan sebagai ajaran adiluhung, tetapi doktrin yang boleh digadaikan atau dikomersialisasikan.

Mereka itu bahkan terdorong membenarkan prinsip simbiosis mutualisme (saling menguntungkan) sebagai ilah kontemporer yang menuntutnya wajib "bersujud" atau selalu mengiblalitanya supaya mendapatkan keuntungan besar. Industri pormografi merupakan bentuk "korporasi kemaksiatan" yang sedang dijadikan ilah (Tuhan) kontemporer. Banyak manusia yang terperosok dalam menjadikan aspek-aspek kepentingan yang diburunya sebagai tuhan yang dipuja-pujanya.

Hal itu menunjukkan, bahwa pemeluk agama tidak steril dari tuduhan melakukan perbuatan tercela. Mereka ada yang senang melibatkan diri dan mengamankan aktifitas ilegalnya dalam pembesaran "korporasi kemaksiatan", yang dari usaha bermodus disnormatifitas ini, mereka bisa memperkaya diri atau mendapatkan keuntungan berlimpah.

${ }^{4}$ Ibid. 
Para pemeluk agama itu juga manusia, yang memang bisa saja salah, tidak imun dari godaan, atau tidak selalu teguh pendirian (istiqamah) ketika godaan mengganggu dan mencoba menawarkan keuntungan dan kesenangan berlapis, termasuk kesenangan biologis, namun mereka sedang atau telah terperosok dalam atmosfir arus perubahan gaya hidup yang sangat membahayakan, yang potensial mengamputasi dan bahkan "mematikan" doktrin agama.

Hal itu sebenarnya tidak berbeda dengan pernyataan filosof Frederick Nietzshe, ${ }^{5}$ yang menyebut, bahwa dalam diri manusia yang berburu kepentingan dan kesenangan duniawi, Tuhan telah mati. Kalau tuhan masih hidup dalam dirinya, tentulah manusia pintar dan terpelajar serta sedang berkedudukan mapan tidak akan sampai "mematikan" Tuhan dalam aktiitas kehidupannya.

Pandangan filosof itu dapat ditafsirkan secara hermeneuitik, bahwa ia (Nietzsche) tidak menginginkan masyarakat itu berjalan tanpa kawalan doktrin keagamaan. Kerusakan moral di masyarakat yang sangat parah, mulai dari dunia pendidikan, budaya, politik, dan hukum misalnya, merupakan bagian dari jenis penyakit yang sebenarnya menuntut masyarakat untuk kembali ke jalan Tuhan (agama).

Ketika negeri ini sedang dihadapkan beragam bencana, termasuk bencana atau ujian produk hiburan illegal seperti video asusila dimanamana, masyarakat atau pemeluk agama idealitasnya melakukan refleksi dengan suatu pertanyaan, mengapa bencana masih selalu atau sering bersama kita? Mengapa orang-orang yang tidak berdosa ikut menjadi bagian dari "kebersamaan"? mengapa masyarakat yang dikenal sebagai muslim terbesar di muka bumi ini, justru sering menghadapi berbagai macam bencana yang potensial menghancurkannya? Sejumlah pertanyaan ini menandakan, bahwa ada banyak problem yang berkategori serius yang sedang menguji bangunan peradaban manusia.

\section{Memahami Hedonisme}

Salah satu akar masalah yang bisa digunakan untuk menjawab permasalahan itu adalah kecenderungan gaya hidup masyarakat Indonesia yang semakin hedonisme. Pola hidup hedonisme merupakan salah satu pola yang dapat berdampak terhadap kehancuran masyarakat. Karena dalam pola hidup ini, manusia cenderung melupakan tuhannya. ${ }^{6}$

${ }^{5}$ Subhan Jalal, Belajar Mencari Tuhan di Tengah Dahaga Jiwa, (Jakarta: GravIndonia, 2011), 109.

${ }^{6}$ Ahmad Mustofa, Islam dan Globalisasi Hedonisme (Membaca Model-model Penghancuran Masyarakat Islam), (Surabaya: Lentera Media, 2012), 34. 
Hedonisme adalah pandangan hidup yang menganggap bahwa orang akan menjadi bahagia dengan mencari kebahagiaan sebanyak mungkin dan sedapat mungkin menghindari perasaan-perasaan yang menyakitkan. ${ }^{7}$ Kata hedonisme diambil dari Bahasa Yunani hédonismos dari akar kata hèdone,, artinya "kesenangan". ${ }^{.}$Paham ini berusaha menjelaskan adalah baik apa yang memuaskan keinginan manusia dan apa yang meningkatkan kuantitas kesenangan itu sendiri. ${ }^{9}$

Hedonisme muncul pada awal sejarah filsafat sekitar tahun 433 SM. Hedonisme ingin menjawab pertanyaan filsafat "apa yang menjadi hal terbaik bagi manusia?" Hal ini diawali dengan Sokrates yang menanyakan tentang apa yang sebenarnya menjadi tujuan akhir manusia. ${ }^{l}$ Lalu Aristippos dari Kyrene (433-355 SM) menjawab bahwa yang menjadi hal terbaik bagi manusia adalah kesenangan. Aristippos memaparkan bahwa manusia sejak masa kecilnya selalu mencari kesenangan dan bila tidak mencapainya, manusia itu akan mencari sesuatu yang lain lagi. Pandangan tentang 'kesenangan' (hedonisme) ini kemudian dilanjutkan seorang filsuf Yunani lain bernama Epikuros (341-270 SM). Menurutnya, tindakan manusia yang mencari kesenangan adalah kodrat alamiah. Meskipun demikian, hedonismeEpikurean lebih luas karena tidak hanya mencakup kesenangan badani saja, seperti Kaum Aristippos, melainkan kesenangan rohani juga, seperti terbebasnya jiwa dari keresahan. ${ }^{10}$

Hedonisme adalah satu cara yang dipropaganda oleh Barat sebagai senjata yang empuk yang dikembangkan di indonesia, hedonisme adalah budaya orang-orang Barat yang dikemas sedemikian sederhana dengan tawaran-tawaran mudah dan mewah yang kemudian diberikan kepada masyarakat indonesia. Namun sebenarnya hedonisme yang dicetuskan oleh Articulus (bapak hedonisme) tidak bermakna seperti dewasa ini, hedonidme telah mengalami pergeseran makna atas pemahaman masyarakat menjadi suatu konsep yang hanya berorientasi kepada materi. Inilah makna hedonisme bagi umumnya kebanyakan masyarakat sekarang ini. ${ }^{11}$ Hidup manusia yang terperosok pada hedonisme ibarat menjalani hidup dalam kekuasaan kesenangan duniawi atau cengkeraman kapital. ${ }^{12}$ Manusia dalam kategori ini adalah manusia yang gagal (muflisun)

${ }^{7}$ Franz Magnis-Suseno. Etika Dasar; Masalah-masalah pokok Filsafat Moral. (Yogyakarta: Kanisius, 1987), 114.

${ }^{8}$ Henk ten Napel. Kamus Teologi. (Jakarta: BPK Gunung Mulia, 2009), 158.

${ }^{9}$ K. Bertens. Etika. (Jakarta: Gramedia, 2000), 235-238.

${ }^{10}$ Ibid.

${ }^{11}$ Immawati Kunti Rifhani, http://immfaiumy.blogspot.com/2013/04/tinjauanislam-tentang-budaya-hedonisme.html, akses 11 Maret 2019.

${ }^{12}$ Ahmad Mustofa, Op.Cit, 46. 
Orang yang hanya memandang bahwa kesenangan, kenikmatan dan kebahagiaan baik lahir atau batin menjadi tujuan utama dalam hidup manusia di dunia ini. Sehingga paham hedonisme merupakan suatu cara pandang tertentu dalam memahami hidup manusia di dunia. Dalam Kamus Besar Bahasa Indonesia, hedonisme diartikan sebagai pandangan yang menganggap bahwa kesenangan dan kenikmatan materi sebagai tujuan utama dalam hidup (KBBI, edisi ketiga, 2001). Dari pengertian tersebut dapat ditarik kesimpulan, bahwa hedonisme lebih menitikberatkan kepada jasmani dari pada rohani, berupa kesenangan sesaat yaitu kesenangan duniawi. Cinta pada dunia beserta segala kemewahan yang terlihat dan dirasakan oleh panca indera manusia. ${ }^{13}$ Cinta pada duniawi secara berlebihan merupakan bentuk reduksi cinta pada ilahi. Tuhan dijadikannya tidak mendapatkan tempat dalam kehidupan pemeluk agama akibat dimenangkannya perburuan dan pemutlakan cinta pada harta dan kepentingan biologis duniawi lainnya. ${ }^{14}$

Hal ini sangat bertolak belakang sekali dengan syariat islam, dimana islam adalah agama yang damai, agama dunia akhirat. Islam tidak hanya memandang aspekduniawi saja tetapi juga ukhrowi. Kesenangan dunia hanyalah kesenangan sementara selama di dunia, sedangkan kehidupan kekal adalah kehidupan akhirat. Di dunia tidak hanya kesenangan materi dan lahir yang manusia kejar, tetapi di dunia manusia memiliki tugas sebagai khalifah yakni memimpin diri sendiri dan manusia lain untuk kembali kepada yang menciptakan dengan sebaik-baik keadaan dan amal ibadah yang maksimal. ${ }^{15}$

Islam tidak sependapat dengan paham hedonisme, hedonisme hanyalah pengejar modernitas fisik. Dan dalam islam tidak mengajarkan hal yang seperti itu, sebagaimana kutipan terjemahan dalam Q.S. Hud, ayat 116, yang berbunyi '....dan orang-orang yang zalim hanya memeningkan kenikmatan yang mewah yang ada pada mereka, dan mereka adalah orangorang yang berdosa'. yang lebih meresahkan lagi budaya hedonisme seolah telah menjadi ideologi bagi kaum muda yang tidak tabu lagi untuk dilakukan. ${ }^{16}$ Kaum muda diseret oleh pola hidup hedonisme sampai ke ranah mengkhawatirkan. Mereka bahkan merasa harus menjadi pelaku yang secara terus menerus menghidupkan dan menyebarkannya kemana-mana. ${ }^{17}$ Mereka ini bahkan bangga atau bahagia menjdi pengikut hedonisme.

${ }^{13}$ Immawati Kunti Rifhani, Op.Cit.

${ }^{14}$ Ahmad Mustofa, Op.Cit, 47.

${ }^{15}$ Immawati Kunti Rifhani, Op.Cit.

16 Ibid.

${ }^{17}$ Laili Rachmawati, Jihad Terbesar Melawan Budaya Barat, (Yogyakarta: Lembaga Kajian Keislaman dan Kebudayaa (LKIK), 2011), hal. 75. 
Kebahagiaan yang dituju oleh Kaum Epikurean adalah kebahagiaan pribadi (privatistik). ${ }^{18}$

Seorang ulama Timur Tengah, Ali syariati pernah berkata tantangan terbesar bagi remaja muslim saat ini adalah budaya hedonisme, yakni kesenangan adalah hal yang paling penting dalam hidup. Budaya yang bertentangan dengan islam ini digemari dan dijadikan sebagai gaya hidup (life style) bagi kawula muda masa kini, tidak memandang status sosial, ekonomi dan pendidikan, baik kaya atau miskin, ningrat atau jelata, sarjana atau proletar, di desa atau di kota, seolah sepakat menjadikan hedonisme sebagai budaya modern mereka. Ini menjauhkan dan mengeluarkan mereka dari gaya hidup yang beradab, yaitu dari hukum Allah SWT yang menciptakan manusia. ${ }^{19}$

Manusia adalah makhluk yang tidak pernah bersyukur atas apa yang diperoleh, senantiasa mencari yang lebih dari apa yang sudah didapatkannya. Sebagaimana kalau kita tahu tentang makna syukur. dalam buku Living smart, Muhammad Nazhif Mansyur menegaskan tentram, ridha dan tenang hakikatnya bersumber dari pancaran energi syukur. Dengan bersyukur Allah senantiasa melimpahkan nikmat lebih dari apa yang kita dapat sekarang, tetapi manusia jarang menyadari akan hal penting tersebut. ${ }^{20}$ Kekurangan, apalagi kehilangan etika ilahiah dalam diri manusia, membuatnya gampang terlena mengikuti pesona godaan perubahan di tengah masyarakat. ${ }^{21}$

Manusia lebih cenderung mencari yang lebih dengan berbagai cara seperti halnya para hedonis. Dalam islam juga menegaskan bahwa segala hal yang terjadi kepada manusia adalah hal yang baik selama manusia itu mampu menyikapinya dengan baik pula. ${ }^{22}$

Dalam sebuah hadist yang diriwayatkan oleh Muslim dan Ahmad, disebutkan "sungguh menakjubkan perilaku orang mukmin. Semua keadaan adalah baik baginya. Jika memperoleh kesenangan dia bersyukur, dan yang demikian itu adalah baik baginya; dan jika dia ditimpa kesusahan, dia bersabar, dan yang demikian itu adalah baik baginya. Perilaku seperti itu hanya ada pada diri seorang mukmin".

Sebagai orang islam, haruslah tau apa yang baik dan apa yang buruk bagi diri kita sendiri, islam telah mengajarkan banyak hal. Hingga remaja pun dimana kebanyakan orang menganggap bahwa dunia remaja adalah dunia pencarian jati diri, namun diri kita sendiri lah yang tau apa yang

\footnotetext{
${ }^{18}$ Franz Magnis-Suseno. 13 Tokoh Etika. (Yogyakarta: Kanisius, 1997), 49-50.

${ }^{19}$ Immawati Kunti Rifhani, Op.Cit.

${ }^{20}$ Ibid.

${ }^{21}$ Laili Rachmawati, Op.Cit.

${ }^{22}$ Immawati Kunti Rifhani, Op.Cit.
} 
menjadi kebutuhan kita. Sebagai seorang muslim yang sudah mengetahui tentang budaya hedonisme ini, haruslah tau bagaimana bersikap. Tetap kritis dalam melihat kemunculan tsaqafah atau budaya selain islam. Dunia memang mudah untuk menjalankan segala hal kebaikan apa lagi keburukan. ${ }^{23}$

\section{Mengalahkan Pola Hidup Hedonisme}

Ada suatu dialog menarik antara Umul Mu'minin Zainab RA dengan Nabi Muhammad SAW. Zainab bertanya kepada Nabi, "apakah kita akan binasa di tengah-tengah orang-orang jahat atau munculnya $Y a{ }^{\prime} j u j ~ M a ' j u j$, sedangkan diantara kita masih ada orang-orang saleh"? "Ya", jawab Nabi, bilamana terdapat banyak kejahatan (kemaksiatan).

Dialog Nabi dengan isterinya itu mengajarkan mengenai rumus hubungan signifikan antara kebinasaan dan kehancuran yang menimpa umat, rakyat dan bangsa dengan perilaku criminal, "korporasi kemaksiatan" atau segolongan orang yang berjuluk $Y a$ 'juj Ma'juj.

Yakjuj Ma'juj memang bisa muncul di tengah masyarakat, di dalam diri umat beragama, diantara pilar negara, diantara anak-anak, diantara isteri-isteri, diantara suami-suami, diantara pemimpin-pemimpin, dan di dalam perbuatan-perbuatan kita. Ia bisa menjadi diri kita, mengendalikan dan menguasai kaum berdasi, kaum beragama, atau siapapun yang menyukai jagat hedonisme.

Maraknya pelanggaran moral atau beragam "korporasi kemaksiatan" atau produksi amoralitas di negeri ini bisa mendorong Allah SWT mengirimkan hukuman yang setimpal (adil), diantaranya dalam bentuk hancurnya citra diri sebagai masyarakat dan bangsa beragama.

Allah sebenarnya tidak serta merta menjatuhkan azab di luar batas kemampuan dan keberdayaan manusia, kalau saja perilaku manusia tidak demikian terperosok dalam hedonisme yang diwujudkannya dalam bentuk perilaku animalistik-dehumanistik dan memperluas berbagai bentuk keasusilaan dimana-mana.

Komunitas pemeluk Islam yang tidak mampu memberikan solusi pada persoalan moral dan kemanusiaan tidak akan punya masa depan yang cerah, demikian pernyataan pemikir kenamaan Fazlur Rahman dalam Major Themes of the Qur'an (1980). Pernyataan Rahman ini mengisaratkan bahwa hidup seseorang itu ditentukan lewat "karya", prestasi etik dan praksis

\footnotetext{
${ }^{23}$ Ibid.
} 
amaliah sosialnya yang bertujuan dan berorientasi pada pembaruan dan pencerahan harkat kehidupannya. ${ }^{24}$

Pencerahan kehidupan bermasyarakat hanya mungkin terlahir melalui manusia-manusia beragama yang jiwanya "membara" atau selalu berupaya untuk melakukan reformasi dan transformasi nilai dalam diri dan kepemimpinannya. Tidak akan ada hasil yang menggembirakan (mencerahkan) yang bisa ditunai oleh masyarakat dan bangsa tanpa didahului oleh gerakan pembumian moral.

Komitmen dan teguh pendirian di kalangan pemeluk agama dari pressure gaya hidup hedonisme merupakan senyawa dan konvergensi nilainilai moralitas luhur yang dijadikan parameter integritas keimanan seseorang. Kalau keteguhan pada nilai-nilai moral bisa ditegakkannya, maka hal ini merupakan modal besarnya untuk layak disebut beragama dalam konstruksi bermasyarakat dan bernegara.

\section{PENUTUP}

Dalam agama Islam sudah diajarkan atau digariskan kepada setiap pemeluknya untuk menjadi manusia-manusia yang taat dan konsisten memegang teguh agamanya, pada saat kapan, dimanapun dan berhubungan dengan siapapun. Sayangnya, tidak sedikit di kalangan pemeluk agama Islm ini yang terjerumus dalam berbagai bentuk penyimpangan.

Mereka membenarkan jenis-jenis perilaku yang bertentangan dengan doktrin Islam, dan bahkan apa yang diperbuatnya ini bukan hanya merugikan dirinya, melainkan juga merugikan orang lain dan citra agama yang dipeluknya (Islam). Kerugian atau dampak demikian kadang diabaikannya.

\section{DAFTAR PUSTAKA}

\section{Buku-Buku}

Ahmad Mustofa, 2012, Islam dan Globalisasi Hedonisme (Membaca Model-model Penghancuran Masyarakat Islam), Surabaya: Lentera Media.

Franz Magnis-Suseno. 1987, Etika Dasar; Masalah-masalah pokok Filsafat Moral. Yogyakarta: Kanisius,. , 1987, 13 Tokoh Etika. Yogyakarta: Kanisius.

Henk ten Napel. 2009, Kamus Teologi. Jakarta: BPK Gunung Mulia. K. Bertens. 2000, Etika. Jakarta: Gramedia. 2012, hal. 5 .

${ }^{24}$ Nurul Qomar, Agama Islam yang Membebaskan, Pustaka Madani, Jakarta, 
Laili Rachmawati, 2011, Jihad Terbesar Melawan Budaya Barat, Yogyakarta: Lembaga Kajian Keislaman dan Kebudayaan (LKIK).

Nurul Qomar, 2012, Agama Islam yang Membebaskan, Jakarta: Pustaka Madani.

Subhan Jalal, 2011, Belajar Mencari Tuhan di Tengah Dahaga Jiwa, Jakarta: Grav-Indonia.

\section{Internet}

Abdain,http://abdain.wordpress.com/2010/04/11/fungsi-agama-bagikehidupan/. Akses 15 Maret 2019.

http://strafaelyudistira.wordpress.com/2013/01/29/peranan-agama/, akses 12 Maret 2019.

Immawati Kunti Rifhani, http://immfaiumy.blogspot.com/2013/04/tinjauanislam-tentang-budaya-hedonisme.html, akses 11 Maret 2019. 